\title{
Pengembangan Media Pembelajaran Adaptif Berbasis Fuzzy Expert System untuk Meningkatkan Prestasi Belajar Siswa
}

\author{
Sumarlin \\ Sistem Informasi, Stikom Uyelindo Kupang
}

\begin{abstract}
INFO ARTIKEL
\section{Riwayat Artikel:}

Diterima: 13-02-2021

Disetujui: 25-02-2021

\section{Kata kunci:}

Pembelajaran Adaptif

Sistim Pakar

Fuzzy

Afektif

Kognitif

Abstract: Several researchers have pointed out the importance of providing guidance and support for individual learning. In the last few decades, most of the research on how to develop adaptive learning systems to address this problem has been primarily based on students' cognitive status, such as their learning achievement. However, some educators have indicated the need to consider the affective status of learners. Therefore, this study proposes an expert systems approach by considering the affective and cognitive status of individual learners. The adaptive learning system is implemented based on the proposed approach. In addition, it is necessary to conduct an experiment on one of the subjects to compare the learning achievement and perceptions of students who carry out learning with an adaptive learning system with an analysis of affective and cognitive status. In addition, based on the results of the literature study it was found that the proposed approach helped low achieving students complete the learning tasks, while those who studied with the conventional cognitive factor-based approach were more likely to give up completing some learning tasks, and rely more on detailed versions of the learning tasks. teaching materials.
\end{abstract}

\section{Alamat Korespondensi:}

Sumarlin,

Sistem Informasi

STIKOM Uyelindo Kupang

Jl. Perintis Kemerdekaan I, Kayu Putih, Kec. Oebobo, Kota Kupang, Nusa Tenggara Tim. 85228

Email: sumar.lin94@yahoo.com

\begin{abstract}
Abstrak: Beberapa peneliti telah menunjukkan pentingnya memberikan bimbingan dan dukungan untuk belajar secara individu. Dalam beberapa dekade terakhir, sebagian besar penelitian tentang bagaimana cara mengembangkan sistem pembelajaran adaptif untuk mengatasi masalah ini terutama berdasarkan status kognitif siswa, seperti prestasi belajar. Namun, beberapa pendidik telah menunjukkan perlunya mempertimbangkan status afektif peserta didik. Oleh karena itu, penelitian ini mengusulkan pendekatan sistem pakar fuzzy dengan mempertimbangkan status afektif dan kognitif individu peserta didik. Sistem pembelajaran adaptif dilaksanakan berdasarkan pendekatan yang diusulkan. Selain itu, perlu dilakukan percobaan pada salah satu mata pelajaran untuk membandingkan prestasi belajar dan persepsi siswa yang melakukan pembelajaran dengan sistem pembelajaran adaptif dengan analisis status afektif dan kognitif. Selain itu, berdasarkan hasil penelitian ditemukan bahwa aplikasi yang dikembangkan membantu siswa yang berprestasi rendah berhasil menyelesaikan tugas-tugas pembelajaran, sementara mereka yang belajar dengan pendekatan berbasis faktor kognitif konvensional lebih cenderung menyerah dalam menyelesaikan beberapa tugas pembelajaran, dan lebih bergantung pada versi rinci dari bahan ajar.
\end{abstract}




\section{PENDAHULUAN}

Dalam satu pendekatan tradisional pada banyak instruksional, karena keterbatasan faktor-faktor seperti proses pengajaran, tenaga manusia, dan sebagainya, instruktur hanya dapat menyediakan semua siswa dengan materi yang sama, dan mereka cenderung menggunakan pendekatan pengajaran yang identik dan tingkat kemajuan. Sulit untuk mempertimbangkan kebutuhan belajar individu siswa (Sampayo-Vargas et al., 2013). Artinya, siswa dengan tingkat kemahiran yang lebih baik dibatasi oleh kemajuan pengajaran instruktur sehingga mereka tidak dapat menggunakan waktu selama kelas secara efektif untuk belajar. Disisi lain, siswa dengan tingkat kemahiran yang tidak memadai mungkin tidak dapat memahami konten kursus (Looi et al., 2009). Untuk mengatasi masalah ini, peneliti telah mengusulkan model pembelajaran adaptif yang berpusat pada siswa; Artinya, model yang memperhitungkan perbedaan individu siswa dalam desain bahan ajar untuk memperoleh prestasi belajar yang lebih baik (Islam et al., 2015).

Menggunakan teknologi kecerdasan buatan (AI) untuk mensimulasikan pengetahuan dan pengalaman guru untuk memberikan dukungan atau bimbingan yang dipersonalisasi kepada setiap siswa telah diakui sebagai solusi potensial (Pai et al., 2020; Xiao \& Yi, 2020). Beberapa peneliti telah mulai mengembangkan sistem pembelajaran adaptif tersebut dengan menggunakan teknologi AI. Misalnya, (Pai et al., 2020) mengusulkan sistem bimbingan cerdas untuk membantu siswa kelas lima mempelajari ilmu matematika tentang perkalian dan pembagian. Mereka menemukan bahwa sistem bimbingan belajar cerdas tidak hanya meningkatkan prestasi belajar matematika siswa, tetapi juga meningkatkan motivasi belajar mereka. (Hooshyar et al., 2016) menerapkan penilaian formatif berbasis game online dalam sistem bimbingan cerdas berbasis diagram alur. Mereka menjelaskan bahwa ke 52 mahasiswa tersebut mengalami peningkatan minat belajar, sikap dan prestasi belajar ilmu komputer setelah kegiatan pembelajaran. Hasilnya menunjukkan bahwa kelompok siswa menunjukkan strategi pencarian bantuan yang lebih baik.Sistem pembelajaran adaptif dapat meningkatkan kinerja belajar siswa (Truong, 2016).

Domain kognitif mencakup ingatan, pemikiran, pengenalan, dan penerapan seseorang terhadap sesuatu. Ini menekankan bahwa fitur utama dari pengetahuan adalah perolehan dan penerapan pengetahuan (Krathwohl et al., 1964). Para peneliti juga mengungkapkan bahwa pembelajaran adaptif seharusnya tidak hanya mempertimbangkan status kognitif (Nakic et al., 2015); sebaliknya, faktor emosional peserta didik, seperti perkembangan dan perubahan minat, sikap, nilai, penghargaan, dan adaptasi seseorang, perlu diperhitungkan (Krathwohl et al., 1964). Misalnya (Kim et al., 2013) menunjukkan bahwa karakteristik dan ciri kepribadian siswa juga merupakan faktor penting yang mempengaruhi pembelajaran yang dipersonalisasi. Oleh karena itu, dalam perkembangan pembelajaran adaptif, selain status kognitif siswa, faktor-faktor seperti sikap belajar siswa, minat belajar, dan kasih sayang merupakan hal-hal yang perlu mendapat perhatian. Misalnya, (Ehrman et al., 2003) menunjukkan bahwa perbedaan pelajar mencakup tiga faktor berikut: strategi belajar dan kasih sayang (misalnya, kecemasan dan sikap belajar). Selain itu, (Kobsa et al., 2001) lebih lanjut menetapkan bahwa untuk mencapai pembelajaran "adaptif" yang benar, berbagai aspek yang berbeda harus dimasukkan dan dipertimbangkan.

Untuk mengatasi masalah tersebut, maka penelitian ini bertujuan untuk mengembangkan sistem pembelajaran adaptif dengan mempertimbangkan faktor afektif dan kognitif. Untuk mengeksplorasi keefektifan pendekatan yang diusulkan, harus dilakukan sebuah eksperimen untuk mengevaluasi efek dari sistem yang dikembangkan terhadap prestasi belajar dan beban kognitif siswa.

\section{METODE}

Pengembangan media pembelajaran adaptif berbasis fuzzy expert system termasuk Research and Development (R\&D) dan menggunakan model ADDIE (Analysis, Design, Development, Implementation, Evaluation). Perancangan dan pengembangan media ini menggunakan model pengembangan perangkat lunak melalui 5 tahap yang meliputi: Analisis kebutuhan, Perancangan media, Pengembangan media, Pengujian, dan implementasi. Pengambilan sampel menggunakan teknik purposive sampling. Metode dan instrumen pengumpulan data yang digunakan adalah non tes. Teknik pengumpulan, yaitu dengan menggunakan interview dan kuesioner. Instrumen pengumpulan data dengan menggunakan lembar angket kelayakan dan kemenarikan respon siswa terhadap pengembangan media pembelajaran dengan. Teknik analisis data yang digunakan dalam penelitian dan pengembangan yaitu, deskriptif kuantitatif untuk mengolah data dalam bentuk skor dari penilaian oleh validator dan respon siswa, sedangkan deskriptif kualitatif untuk mendeskripsikan data berupa komentar 
saran perbaikan dari validator. Adapun teknik penilaian kelayakan dan kemenarikan untuk analisis data dengan menggunakan skala likert dengan skala penilaian 1-4.

\section{HASIL}

\section{Kecerdasan buatan dalam pembelajaran adaptif}

Kecerdasan buatan mengacu pada sistem yang mensimulasikan manusia untuk membuat penilaian dan keputusan yang menunjukkan karakteristik kecerdasan manusia (Akerkar, 2014). Dalam beberapa dekade terakhir, teknologi AI telah diadopsi oleh para peneliti untuk memberikan panduan dan dukungan pembelajaran yang dipersonalisasi untuk setiap siswa dalam berbagai kursus, seperti struktur data (Daghestani et al., 2020), pemrograman komputer (Palanca, Terrasa, Carrascosa, \& Julián, 2019) dan matematika (Pai et al., 2020). Selanjutnya (Monova-Zheleva, 2005)mendefinisikan pembelajaran adaptif sebagai model pembelajaran yang menyediakan konten pembelajaran yang sesuai berdasarkan kebutuhan pengguna (Yau \& Joy, 2010); kebutuhan ini dapat dibenarkan dan dievaluasi dengan menggunakan standar teknologi pembelajaran seperti profil peserta didik, definisi kompetensi, aturan pengurutan, objek pembelajaran, dan sebagainya. (Van Rosmalen et al., 2006) menganggap pembelajaran adaptif sebagai kemampuan untuk memperoleh informasi melalui kinerja tugas di tempat peserta didik atau hasil evaluasi dalam rangka meningkatkan pengalaman belajar peserta didik secara individu (Zhao \& Okamoto, 2011).

Dalam upaya untuk membantu peserta didik mengklarifikasi kesalahpahaman mereka selama proses pembelajaran mereka, (Looi et al., 2009) mengembangkan aturan asosiasi sistematis untuk setiap konsep pembelajaran, dan menyajikan konten pembelajaran yang dipersonalisasi dan jalur pembelajaran berdasarkan status kognitif peserta didik yang berbeda setelah mereka memberikan jawaban yang salah, yang kemudian mengklarifikasi kesalahpahaman mereka dan meningkatkan prestasi belajar mereka.(Tseng et al., 2008) mengembangkan sistem pembelajaran yang menyediakan konten pembelajaran yang dipersonalisasi berdasarkan status kognitif. Sistem menyiapkan materi pembelajaran utama dan tes hasil belajar untuk setiap materi; siswa harus membaca materi dalam sistem pembelajaran dan menyelesaikan tes hasil belajar. Sistem pembelajaran kemudian akan menyediakan materi pembelajaran dengan tingkat kesulitan yang memadai untuk kegiatan pembelajaran selanjutnya berdasarkan nilai tes hasil belajar siswa pada materi tersebut sebagai acuan untuk mengevaluasi status kognitifnya. Ini dapat secara efektif meningkatkan prestasi belajar peserta didik.

\section{Sistem pembelajaran adaptif berbasis sistem pakar dengan faktor afektif dan kognitif}

Sistem pembelajaran adaptif berbasis faktor afektif dan kognitif diimplementasikan menggunakan HTML5, CSS3, JavaScript dan MySQL, yang terdiri dari modul pembelajaran, modul pengujian, modul pencatatan status pembelajaran, dan modul sistem pakar, seperti yang ditunjukkan pada Gambar 1. Model pembelajaran memungkinkan siswa untuk belajar dengan menonton video online dan melengkapi lembar pembelajaran. Model pengujian digunakan untuk melakukan tes untuk mengevaluasi tingkat pengetahuan individu siswa. Modul pencatatan status pembelajaran mencatat perilaku belajar setiap siswa dalam log sistem untuk analisis lebih lanjut. Modul sistem pakar digunakan untuk menganalisis status afektif siswa dan untuk menentukan konten pembelajaran untuk individu siswa berdasarkan status afektif dan tingkat pengetahuan mereka.

\section{Modul sistem pakar}

Untuk setiap materi pembelajaran terdapat tiga versi calon materi pembelajaran: yaitu, "versi standar", "versi mendetail", dan versi "lanjutan". Setiap versi terdiri dari materi pembelajaran utama, yang menyajikan konten pembelajaran standar, dan instruksi "standar", "rinci" atau "lanjutan" yang disediakan oleh guru. Dalam versi standar sama dengan konten instruksional tradisional yang guru berikan kepada siswa di kelas. Oleh karena itu, versi ini dirancang untuk siswa dengan pengetahuan standar atau untuk siswa yang status belajarnya tidak jelas ketika memulai materi baru. Versi rinci mengacu pada pengetahuan sebelumnya yang diperlukan untuk mempelajari materis yang disediakan. Versi ini dirancang untuk mereka yang status pembelajarannya di bawah rata-rata. Dalam versi lanjutan menyediakan materi tambahan ekstensif bagi mereka yang prestasi belajarnya di atas rata-rata. 


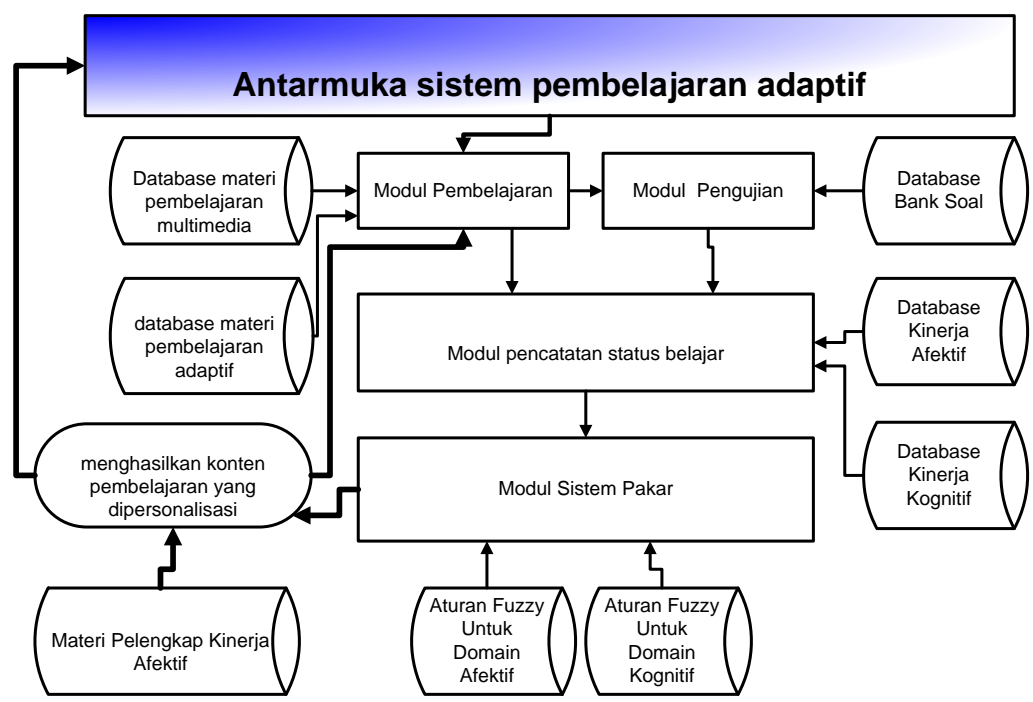

Gambar 1. Struktur Sistem Pembelajaran Adaptif

Dalam sistem pakar, status belajar siswa, seperti jawaban soal latihan, dicatat sebagai status kognitifnya, dan perilaku belajar online mereka dianalisis untuk menentukan status afeksinya. Fuzzy inferencing digunakan untuk menganalisis status kognitif dan afektif siswa dengan menggunakan fungsi keanggotaan fuzzy dan aturan inferensi yang dikemukakan oleh (Tseng et al., 2008) . Sebagai contoh, untuk menganalisis kinerja kognitif siswa ditunjukkan pada Gambar 2.

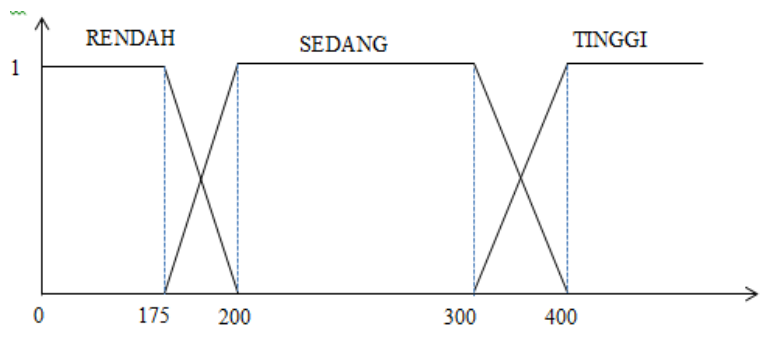

Gambar 2. Grafik Fungsi Kinerja Kognitif

Selain itu, aturan fuzzy berikut digunakan untuk menentukan versi materi pembelajaran yang diberikan kepada masing-masing siswa berdasarkan status pembelajaran terakhir mereka:

1. R1: Jika versi saat ini adalah versi lanjutan dan tingkat pembelajaran Tinggi Then ke versi lanjutan.

2. R2: Jika versi saat ini adalah versi Lanjutan dan tingkat pembelajaran Sedang Then ke versi lanjutan.

3. R3: Jika versi saat ini adalah versi Lanjutan dan tingkat pembelajaran Rendah Then lanjut ke versi lanjutan.

4. R4: Jika versi saat ini adalah versi Lanjutan dan tingkat pembelajaran Buruk Then pelajari pelajaran ini sekali lagi.

5. R5: Jika versi saat ini adalah versi Standar dan tingkat pembelajaran Tinggi Then ke versi lanjutan.

6. R6: Jika versi saat ini adalah versi Standar dan tingkat pembelajaran Sedang Then ke versi Standar.

7. R7: Jika versi saat ini adalah versi Standar dan tingkat pembelajaran Rendah then ke versi Detil.

8. R8: Jika versi saat ini adalah versi Standar dan tingkat pembelajaran Buruk Kemudian pelajari pelajaran ini sekali lagi.

9. R9: Jika versi saat ini adalah versi Detil dan tingkat pembelajaran Tinggi then ke versi Standar.

10. R10: Jika versi saat ini adalah versi Detil dan tingkat pembelajaran adalah Sedang Lalu ke versi Detail.

11. R11: Jika versi saat ini adalah versi Detil dan tingkat pembelajaran Rendah Lalu ke versi Detil.

12. R12: Jika versi saat ini adalah versi Terperinci dan tingkat pembelajaran Buruk Kemudian pelajari pelajaran ini sekali lagi. 
Berkenaan dengan mekanisme analisis kinerja afektif, derajat konsentrasi, kesabaran, dan kemauan belajar siswa dievaluasi berdasarkan log sistem. (1). "Konsentrasi" mengacu pada sejauh mana siswa fokus pada materi. Selama proses ketika siswa membaca materi, sistem akan menampilkan jendela pop-up secara acak. Studi ini memproses waktu yang dibutuhkan siswa untuk merespons jendela dengan menggunakan mesin teori fuzzy; semakin cepat mereka merespon, semakin tinggi tingkat konsentrasi yang mereka miliki, dan sebaliknya. Ketika seorang siswa memiliki konsentrasi yang rendah, maka akan muncul pertanyaan jawaban singkat yang relevan dengan materi pembelajaran untuk menggugah konsentrasi siswa. (2). "Kesabaran" merupakan indikator untuk mengetahui apakah siswa bersabar dengan materi terakhir. Ketika mereka memasukkan ke dalam setiap unit tentang luas diagram, sistem akan mulai menghitung waktu belajar mereka. Jika waktu belajar siswa lebih tinggi dari rata-rata semua siswa, sistem akan menunjukkan pengingat untuk beristirahat. (3). "Kemauan belajar" mengacu pada kesediaan siswa untuk mengabdikan dirinya untuk belajar dengan mengintegrasikan dua variabel konsentrasi dan waktu belajar untuk melakukan teori fuzzy. Jika siswa memiliki kemauan belajar yang rendah, sistem akan menampilkan lelucon untuk mendorong kemauan belajar mereka.

\section{Proses pembelajaran adaptif}

Tiga versi sistem pembelajaran yang diterapkan dalam penelitian ini: (1) Proses pembelajaran adaptif dengan mekanisme analisis kinerja afektif dan kognitif; (2) Proses pembelajaran adaptif dengan mekanisme analisis kinerja kognitif; dan (3) Proses pembelajaran dengan sistem pembelajaran konvensional. Materi pembelajaran dalam sistem ini mencakup empat topik yaitu jajaran genjang, segitiga, trapesium, dan grafik majemuk pada mata kuliah matematika. Proses pembelajaran dari ketiga versi sistem pembelajaran tersebut diberikan sebagai berikut:

1. Proses pembelajaran adaptif dengan mekanisme analisis kinerja afektif dan kognitif: Karena mekanisme analisis kinerja kognitif, siswa memiliki versi materi yang berbeda, yang ditentukan setelah mengevaluasi status kognitifnya dengan teori fuzzy. Dalam hal ini diharapkan, teori fuzzy dapat menentukan materi yang memiliki tingkat kesulitan yang sesuai untuk materi berikutnya. Jika hasilnya buruk, sistem tidak akan menampilkan materi pembelajaran berikutnya; siswa harus tetap berada di materi itu sampai mereka mencapai tingkat kemahiran tertentu. Pada saat yang sama, sistem akan menyelidiki status afektif siswa (konsentrasi, kesabaran, dan kemauan belajar) ketika mereka membaca materi dan melakukan latihan. Melalui teori fuzzy, sistem dapat menilai apakah bantuan yang diberikan memadai.

2. Proses pembelajaran adaptif dengan mekanisme analisis kinerja kognitif: karena mekanisme analisis kinerja kognitif, siswa memiliki versi materi yang berbeda, yang ditentukan setelah mengevaluasi status kognitifnya dengan teori fuzzy. Dalam hal ini teori fuzzy diadopsi untuk menentukan materi dengan tingkat kesulitan yang sesuai untuk materi berikutnya. Jika hasilnya buruk, sistem tidak akan menampilkan materi pembelajaran berikutnya; siswa harus tetap berada di materi itu sampai mereka mencapai tingkat kemahiran tertentu.

3. Proses pembelajaran dengan sistem pembelajaran konvensional: siswa menggunakan materi dalam versi standar untuk belajar selama proses pembelajaran.

\section{Prosedur Eksperimen}

Sebelum melakukan eksperimen, kelompok siswa dibagi dalam 3 kelompok, siswa tersebut diminta untuk mengikuti tes awal 30 menit, dan untuk mengisi kuesioner pra-test. Setelah itu, mereka mulai melakukan kegiatan belajar selama 120 menit. Kelompok eksperimen A memanfaatkan sistem pembelajaran adaptif dengan mekanisme analisis kinerja afektif dan kognitif; kelompok eksperimen B mengadopsi sistem pembelajaran adaptif dengan mekanisme analisis kinerja kognitif; dan kelompok kontrol menggunakan sistem pembelajaran konvensional tanpa mekanisme adaptif. Dalam kegiatan pembelajaran, siswa dari ketiga kelompok tersebut semuanya menggunakan komputer tablet untuk memasuki sistem pembelajaran adaptif. Saat membaca bahan ajar, jika ada item hitung, siswa dapat menggunakan kertas coretan yang dirancang dalam pembelajaran kali ini untuk membantu dalam mengingat dan berpikir. Setelah mereka selesai mempelajari materi pada satu unit, mereka mulai melakukan latihan dalam sistem pembelajaran. Setelah kegiatan pembelajaran, seluruh siswa diminta untuk menyelesaikan post-test selama 40 menit. 


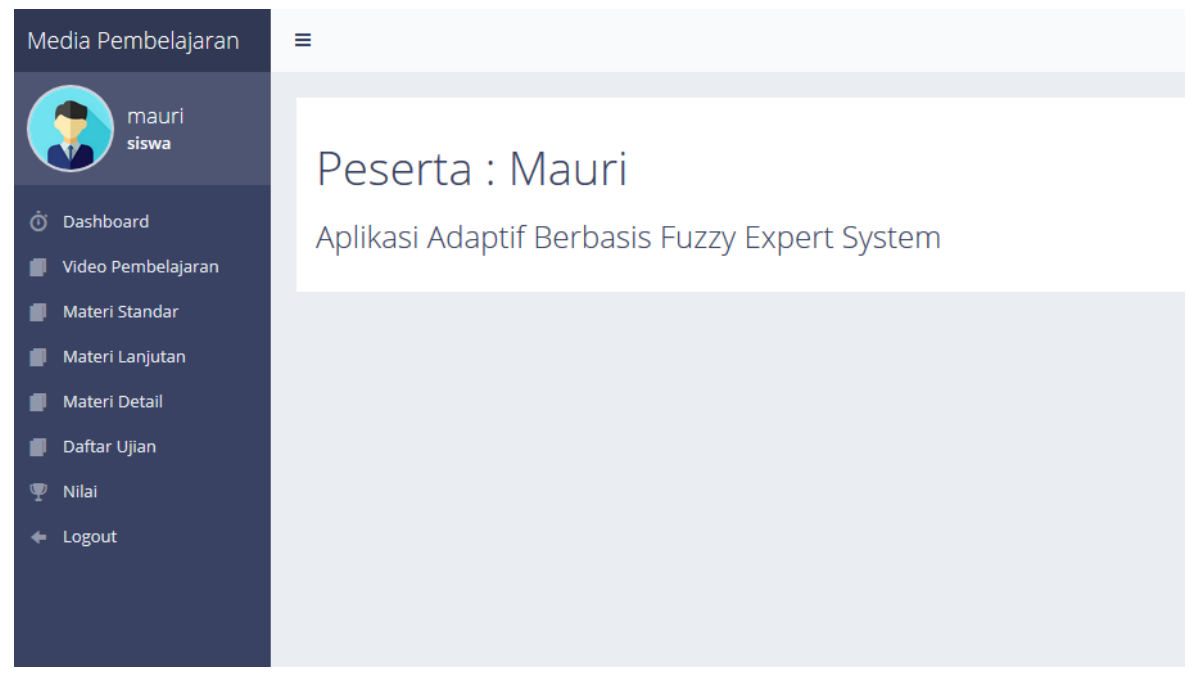

Gambar 3. Antarmuka Media Pembelajaran Adaptif berbasis Fuzzy Expert System

\section{SIMPULAN}

Dalam hal prestasi belajar, siswa yang menggunakan sistem pembelajaran adaptif dengan mekanisme analisis kinerja afektif dan kognitif mengungguli siswa yang menggunakan sistem pembelajaran adaptif hanya dengan mekanisme analisis kinerja kognitif dan siswa yang menggunakan sistem pembelajaran konvensional. Hal ini mengungkapkan bahwa sistem pembelajaran adaptif dengan mekanisme analisis kinerja afektif dan kognitif akan sangat kondusif dalam memfasilitasi prestasi belajar siswa. Pada aspek beban kognitif, tingkat kesulitan dan penataan materi dalam sistem semuanya dapat diterima oleh kelompok siswa. Dengan kata lain, tingkat kesulitan dan beban kegiatan pembelajaran tidak akan menimbulkan beban kognitif yang terlalu tinggi atau terlalu rendah. Dengan adanya media adaptif learning yang menerapakan fuzzy expert system dapat membantu para guru dalam menganalisis sejauh mana tingkat pemahaman siswa dalam mempelajari sebuah materi, dan juga dapat menjadi tolak ukur dalam mengevaluasi kinerja belajar siswa baik dari aspek kognitif maupun afektif yang dapat mempengaruhi hasil belajar siswa.

\section{DAFTAR RUJUKAN}

Akerkar, R. (2014). Introduction to artificial intelligence. PHI Learning Pvt. Ltd.

Daghestani, L. F., Ibrahim, L. F., Al-Towirgi, R. S., \& Salman, H. A. (2020). Adapting gamified learning systems using educational data mining techniques. Computer Applications in Engineering Education, 28(3), 568-589.

Ehrman, M. E., Leaver, B. L., \& Oxford, R. L. (2003). A brief overview of individual differences in second language learning. System, 31(3), 313-330.

Hooshyar, D., Ahmad, R. B., Yousefi, M., Fathi, M., Horng, S. J., \& Lim, H. (2016). Applying an online game-based formative assessment in a flowchart-based intelligent tutoring system for improving problem-solving skills. Computers \& Education, 94(March), 18-36.

Islam, N., Beer, M., \& Slack, F. (2015). E-learning challenges faced by academics in higher education. Journal of Education and Training Studies, 3(5), 102-112.

Kim, J., Lee, A., \& Ryu, H. (2013). Personality and its effects on learning performance: Design guidelines for an adaptive elearning system based on a user model. International Journal of Industrial Ergonomics, 43(5), 450-461.

Kobsa, A., Koenemann, J., \& Pohl, W. (2001). Personalized hypermedia presentation techniques for improving online customer relationships. Knowledge Engineering Review, 16(2), 111-156.

Krathwohl, D. R., Bloom, B. S., \& Masia, B. B. (1964). Taxonomy of educational objectives: the classification of educational goals; handbook... 2. Affective domain. David McKay Company New York.

Looi, C. K., Wong, L. H., So, H. J., Seow, P., Toh, Y., Chen, W., \& Soloway, E. (2009). Anatomy of a mobilized lesson: Learning my way. Computers \& Education, 53(4), 1120-1132.

Monova-Zheleva, M. (2005). Adaptive learning in Web-based educational environments. Cybernetics and Information Technologies, 5(1), 44-55. 
Nakic, J., Granic, A., \& Glavinic, V. (2015). Anatomy of student models in adaptive learning systems: A systematic literature review of individual differences from 2001 to 2013. Journal of Educational Computing Research, 51(4), 459-489.

Pai, K. C., Kuo, B. C., Liao, C. H., \& Liu, Y. M. (2020). An application of Chinese dialogue-based intelligent tutoring system in remedial instruction for mathematics learning. Educational Psychology, 1-16.

Sampayo-Vargas, S., Cope, C. J., He, Z., \& Byrne, G. J. (2013). The effectiveness of adaptive difficulty adjustments on students' motivation and learning in an educational computer game. Computers \& Education, 69(November), 452462.

Truong, H. M. (2016). Integrating learning styles and adaptive e-learning system: Current developments, problems and opportunities. Computers in Human Behavior, 55(February), 1185-1193.

Tseng, J. C., Chu, H. C., Hwang, G. J., \& Tsai, C. C. (2008). Development of an adaptive learning system with two sources of personalization information. Computers \& Education, 51(2), 776-786.

Van Rosmalen, P., Vogten, H., Van Es, R., Passier, H., Poelmans, P., \& Koper, R. (2006). Authoring a full life cycle model in standards-based, adaptive e-learning. Journal of Educational Technology \& Society, 9(1), 72-83.

Xiao, M., \& Yi, H. (2020). Building an efficient artificial intelligence model for personalized training in colleges and universities. Computer Applications in Engineering Education.

Yau, J. Y. K., \& Joy, M. (2010). An adaptive context-aware mobile learning framework based on the usability perspective. International Journal of Mobile Learning and Organisation, 4(4), 378-390.

Zhao, X., \& Okamoto, T. (2011). Adaptive multimedia content delivery for contextaware u-learning. International Journal of Mobile Learning and Organisation, 5(1), 46-63. 